\title{
ECOLOGY OF OWENS VALLEY VOLE (MICROTUS CALIFORNICUS VALLICOLA)
}

\author{
Fletcher C. Nelson ${ }^{1}$, Michael L. Morrison ${ }^{2,4}$, Roel R. Lopez ${ }^{1}$, \\ Fred E. Smeins ${ }^{3}$, and Nova J. Silvy 1
}

Key words: habitat use, distribution, Owens Valley vole, Microtus californicus vallicola, rodent ecology.

Information concerning small mammal ecology in Owens Valley, California, is scarce. Previous studies have focused primarily on taxonomy (Bailey 1898, 1915, Elliot 1903, Hollister 1913, 1914, Grinnell 1922, Hall and Dale 1939, Lidicker 1960) or on species occurring in xerophytic plant associations (Kenagy 1973a, 1973b, Brown 1973, Brown and Lieberman 1973, Matson 1976). Mesic associations, however, comprise approximately 26,880 ha $(\sim 20 \%)$ of Owens Valley. These mesic areas, including riparian corridors, meadows, and agricultural lands, are subject to more intensive and concentrated human use (e.g., livestock grazing, recreation) than drier areas.

Mesic environments are likely to support small mammal communities that differ from those of xeric environments. The distribution of 1 small mammal species, the Owens Valley vole (OVV; Microtus californicus vallicola), a subspecies of the California vole (Microtus californicus), is restricted to mesic vegetation types within the valley. The Sierra Nevada and the Mojave Desert isolate the Owens Valley vole from other subspecies (Hall 1981). The California Department of Fish and Game (CDFG) has listed the Owens Valley vole as a species of special concern (CDFG 2001).

Bailey $(1898,1900)$ first collected and described the Owens Valley vole in 1898, providing its current taxonomic designation. Bailey distinguished the Owens Valley vole from other subspecies of California vole by its comparatively darker pelage, smaller auditory bullae, more abruptly truncated occiput, and presence of a loop on the 4th triangle of the middle upper molar. Kellogg (1918) noted uniform con- vexity in dorsal profile, narrow interpterygoid fossa, and heavy maxillary roots as distinguishing characteristics.

The Museum of Vertebrate Zoology, University of California, Berkeley, holds 108 specimens collected between 1912 and 1957. Although considerable literature exists regarding California vole ecology and taxonomy (Krebs 1966, Lidicker 1980, Ford and Pitelka 1984, Tamarin 1985), its applicability to OVV populations is questionable. Climate, vegetative communities, topography, elevation, and plant association distribution patterns differ substantially between typical California vole study sites (i.e., coastal and inland Mediterranean annual grasslands) and collection locations of the Owens Valley vole. To better understand the ecology of Owens Valley voles, we studied the relative abundance of small mammal species in mesic plant associations of Owens Valley, California. We placed special emphasis on the distribution and habitat use of Owens Valley voles.

Owens Valley lies between the Sierra Nevada and the Inyo-White Mountains in eastern California (primarily Inyo County). The valley supports several cold- and warm-desert plant communities. These shrublands are interspersed with riparian communities associated with the Owens River and its tributaries, natural wetlands, and irrigated and nonirrigated agricultural land. Our study was restricted to the vicinity (within $24 \mathrm{~km}$ ) of Bishop, California, located at the northern end of Owens Valley (Fig. 1). The climate there is characteristic of the southern Great Basin, with low annual precipitation (136 mm) occurring primarily in winter and spring. Annual precipitation has

\footnotetext{
${ }^{1}$ Department of Wildlife and Fisheries Sciences, Texas A\&M University, College Station, TX 77843.

${ }^{2}$ Great Basin Institute and Biology Department, University of Nevada, Reno, NV 89557.

${ }^{3}$ Department of Rangeland Ecology and Management, Texas A\&M University, College Station, TX 77843

${ }^{4}$ Corresponding author. Present address: Department of Wildlife and Fisheries Sciences, 210 Nagle Hall, TAMU 2258, Texas A\&M University, College Station, TX 77843. E-mail: mlmorrison@ag.tamu.edu
} 


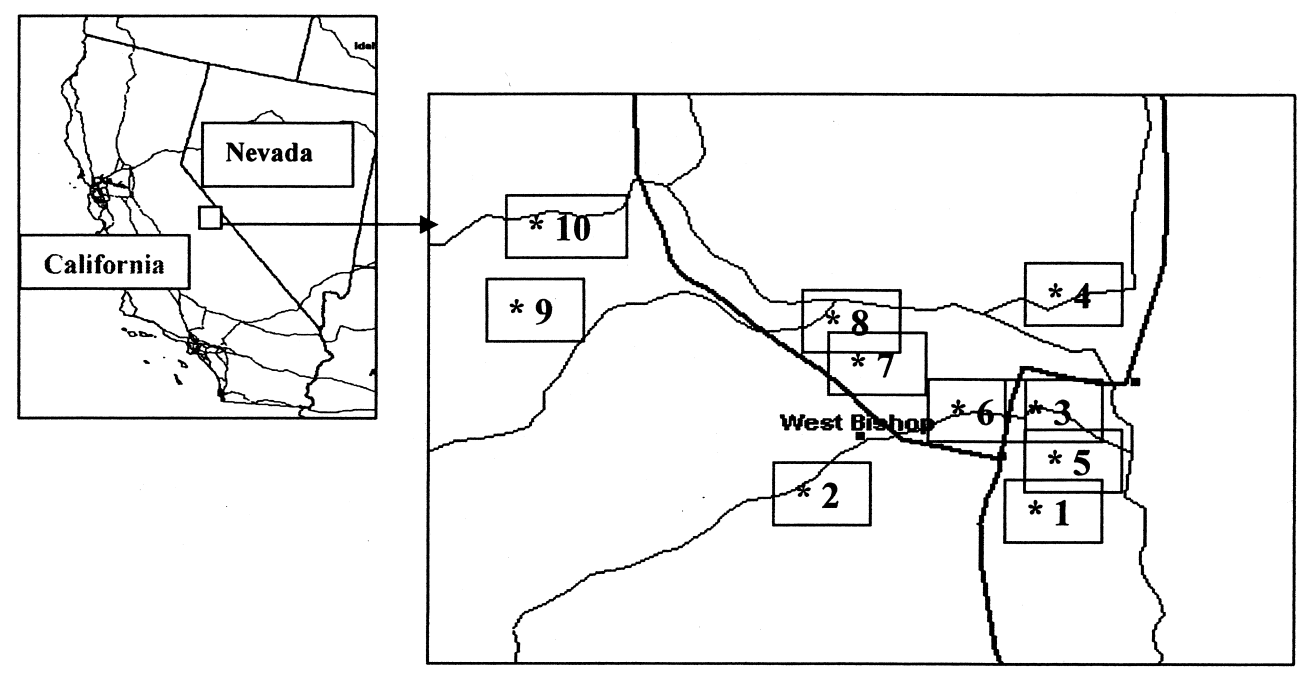

Fig. 1. Arrangement of study sites within Owens Valley, California, 2002. Sites 1 and 5-rabbitbrush meadow, sites 2 and 4 - Great Basin riparian forest, sites 3 and 7 -rush/sedge meadow, site 6-irrigated native meadow (ungrazed), site 8-Great Basin riparian scrub, and sites 9 and 10_irrigated pasture (grazed). Coordinates (UTM) for study sites are available from Los Angeles Department of Water and Power, Bishop Office, Bishop, California. Major unimproved and paved roads are indicated. Scale of panel on the right is approximately 1:100,000.

been lower than average since 1999 (Nelson 2004), although normal January and July average temperatures were $3^{\circ} \mathrm{C}$ and $21^{\circ} \mathrm{C}$, respectively. Elevation at our study sites was between $1250 \mathrm{~m}$ and $1400 \mathrm{~m}$. The 6 plant communities represented in our study area were (1) rabbitbrush (Chrysothamnus nauseosus) meadow, (2) Great Basin riparian forest (Salix spp., Populus spp.), (3) rush/sedge (Juncus spp. / Carex spp.) meadow, (4) native meadow (beardless wildrye [Leymus triticoides]), (5) Great Basin riparian scrub (Salix spp.), and (6) irrigated pasture (exotic grasses, bluegrasses [Poa spp.], and orchardgrass [Dactylis glomerata]). Detailed descriptions of each study site, including plant species composition, are given in Nelson (2004).

We used the Los Angeles Department of Water and Power (LADWP) geographic information system (GIS) database to generate a randomized list of potential survey sites. Vegetation layers were based on an inventory conducted by LADWP between 1984 and 1987 that encompassed approximately 91,863 ha of valley floor. This area was divided into over 2000 parcels of relatively homogeneous vegetative associations based on Holland's (1986) plant community classifications.
We used the LADWP GIS to exclude nontarget plant communities and parcels of insufficient area and then generated a list of suitable parcels in random order. Some potential sites were discarded due to disparities between their classification under the vegetation inventory and their current vegetative community (i.e., considerable succession or disturbance had occurred). We excluded other sites due to presence of livestock or close proximity to areas of human activity. We selected 2 sites each in rabbitbrush meadow (1 and 5), Great Basin riparian forest ( 2 and 4 ), rush/sedge meadow ( 3 and 7 ), and irrigated pasture (9 and 10); and 1 site each in native meadow (6) and Great Basin riparian scrub (8; Fig. 1).

To confirm the general vegetative community classification at each study site, a lineintercept vegetation survey was conducted at each site and additional vegetation data were collected at vole capture locations. Our sampling methods are detailed in Nelson (2004).

We trapped from July 2002 to November 2002 to assess the presence and relative abundance of rodents. Although considerable changes in temperature occurred during this period, animal activity, assessed through trapping and sign observation, appeared stable 
TABLE 1. Index of abundance for 4 small mammal species by plant community, Owens Valley, California, 2002.

\begin{tabular}{|c|c|c|c|c|c|c|c|}
\hline \multirow[b]{2}{*}{ Site } & \multirow[b]{2}{*}{$\begin{array}{l}\text { Plant } \\
\text { community }\end{array}$} & \multirow[b]{2}{*}{$\begin{array}{l}\text { Trap } \\
\text { nights }\end{array}$} & \multicolumn{5}{|c|}{ Abundance (number per 100 trap nights) } \\
\hline & & & $\begin{array}{l}\text { Western harvest } \\
\text { mouse }\end{array}$ & $\begin{array}{l}\text { Deer } \\
\text { mouse }\end{array}$ & $\begin{array}{c}\text { Owens Valley } \\
\text { vole }\end{array}$ & $\begin{array}{l}\text { Little pocket } \\
\text { mouse }\end{array}$ & $\begin{array}{c}\text { All } \\
\text { species }\end{array}$ \\
\hline 1 & Rabbitbrush meadow & 300 & 2.7 & 3.3 & - & - & 6.0 \\
\hline 2 & Riparian forest & 300 & 4.3 & 4.7 & - & - & 9.0 \\
\hline 3 & Rush/sedge meadow & 300 & 1.3 & 1.3 & 0.3 & - & 3.0 \\
\hline 4 & Riparian forest & 180 & 2.8 & 1.7 & - & 0.6 & 5.0 \\
\hline 5 & Rabbitbrush meadow & 300 & 4.0 & 0.3 & - & - & 2.2 \\
\hline 6 & Native meadow & 600 & 0.3 & - & 0.2 & - & 1.0 \\
\hline 7 & Rush/sedge meadow & 300 & 1.3 & - & 0.3 & - & 1.7 \\
\hline 8 & Riparian scrub & 300 & 11.3 & 7.0 & 0.7 & - & 19.0 \\
\hline 9 & Irrigated pasture, grazed & 300 & - & 1.0 & - & - & 1.0 \\
\hline 10 & Irrigated pasture, ungrazed & 300 & 1.3 & 0.3 & 1.3 & - & 3.0 \\
\hline \multicolumn{2}{|c|}{ ALL SITES } & 3180 & 2.7 & 1.8 & 0.3 & 0.0 & 4.8 \\
\hline
\end{tabular}

throughout the study. From July to August, traps were opened only at night (3 nights); thereafter traps were left open day and night (3 nights, 2 days). Trapping was stopped in November due to rising frequency of cold weather fatalities. Each site was trapped once (3 nights), except native meadow, which was trapped twice.

At most sites we established a standard 100 $\mathrm{m} \times 100-\mathrm{m}$ grid with Sherman live-traps (7.6 $\mathrm{cm} \times 8.9 \mathrm{~cm} \times 22.9 \mathrm{~cm})$ at 10 -m intervals. At the 3 riparian sites, transects $60-250 \mathrm{~m}$ in length with traps at $10-\mathrm{m}$ intervals were placed along the waterway to sample the corridor. Supplementary traps were placed on or near suspected OVV runways and burrows (hereafter termed direct trapping). We baited with rolled oats and peanut butter. All captured animals were identified to species, sexed, marked by clipping a small patch of fur from the rump, and released. Number of new individuals captured per 100 trap-nights was used as an index of abundance for each species.

Because of low OVV captures, we surveyed OVV sign (burrowing, feces, grass clippings, grazing, and runways) to obtain additional information on OVV distribution (Village and Myhill 1990). Presence or absence of sign was recorded within a $1-\mathrm{m}$ radius of each trap location. Sign that may have been attributable to other small mammal species (i.e., burrows and grazing) was considered only if associated with sign distinctly characteristic of OVV activity (i.e., runways and feces). Fecal pellets of Owens Valley voles were readily distinguishable from those of other small mammal species by their large size, crescent shape, and coarse texture. Both old and recent OVV sign were considered.

Four species of small mammals were captured (Table 1): western harvest mouse (Reithrodontomys megalotis), deer mouse (Peromyscus maniculatus), Owens Valley vole, and little pocket mouse (Perognathus longimembris). The little pocket mouse was present only at site 4 , and was captured in a saltbush/saltgrass association. The western harvest mouse was absent only from site 9, a heavily grazed, irrigated pasture. Native meadow and grazed, irrigated pasture had the lowest small mammal abundance, and riparian scrub had the highest (Table 1).

Sign surveys indicated past or contemporary presence of Owens Valley voles at all sites. Only sites 3 (64\% of trap locations with vole sign), 6 (23\% with vole sign), and 8 (31\% with vole sign) had prominent vole sign; all other sites had vole sign at $<12 \%$ of trap locations. Only 2 Owens Valley voles were trapped in the first 1980 trap-nights, which included 900 trap-nights at 2 sites ( 3 and 6 ) with conspicuous vole activity. No voles were recaptured. Fresh feces, grass clippings, burrowing debris, and extensive runways were conspicuous at both sites. Lack of correlation between sign indices and OVV captures $(r=0.309, P=$ 0.386) may have been due to the inclusion of old sign in our surveys as well as to low catchability of Owens Valley voles.

Both plant species composition and height varied between and within sites at OVV capture locations (Table 2). Small sample size $(n=8)$ for systematic capture locations prohibited 
TABLE 2. Vegetative characteristics at capture locations of Owens Valley voles, Owens Valley, California, 2002.

\begin{tabular}{|c|c|c|c|c|c|c|c|c|c|}
\hline \multirow[b]{2}{*}{ Site } & \multirow[b]{2}{*}{$\begin{array}{l}\text { Plant } \\
\text { community }\end{array}$} & \multicolumn{3}{|c|}{ Number of captures } & \multicolumn{5}{|c|}{ Percent cover ${ }^{b}$} \\
\hline & & Direct $^{\mathrm{a}}$ & Grid & Total & $\begin{array}{l}\text { Bare ground } \\
\text { and litter }\end{array}$ & Grasses & Forbs & Woody & $\begin{array}{c}\text { Mean height } \\
(\mathrm{cm})\end{array}$ \\
\hline 3 & Rush/sedge meadow & 0 & 1 & 1 & 0.0 & 42.4 & 57.6 & 0.0 & 67 \\
\hline 6 & Native meadow & 2 & 1 & 3 & 28.7 & 61.1 & 4.2 & 6.0 & 28 \\
\hline 7 & Rush/sedge meadow & 2 & 1 & 3 & 4.0 & 45.7 & 2.3 & 48.0 & 57 \\
\hline 8 & Riparian scrub & 3 & 2 & 5 & 6.2 & 60.8 & 4.3 & 16.8 & 32 \\
\hline 9 & Irrigated pasture, grazed & 6 & 0 & 6 & 0.8 & 97.1 & 2.3 & 0.0 & 12 \\
\hline 10 & Irrigated pasture, ungrazed & 1 & 3 & 4 & 0.0 & 81.2 & 18.8 & 0.0 & 29 \\
\hline
\end{tabular}

aCaptures with traps placed at burrow locations.

${ }^{\mathrm{b}}$ Capture location percentages are $<100 \%$ due to water at some capture sites.

statistical analysis of microhabitat selection. However, observations we made while selecting directed trapping locations and conducting sign surveys indicated that voles selected microhabitats within general plant associations. Sign of vole activity was concentrated around irregular features of the study site such as shrubs, patches of dense herbaceous vegetation, fence lines, and waterways. Sites with the highest sign indices (sites 3,6, and 8) had high beardless wildrye cover $(43 \%, 84 \%$, and $20 \%$, respectively). At capture sites, only "unidentified grass species" comprised a higher percentage $(23 \%)$ than beardless wildrye (12\%). At sites 6, 7, and 8, OVV activity was high in and around shrubs. At site 7, all OVV capture locations were on the periphery of an isolated Wood's rose (Rosa woodsii) thicket. All fresh sign in the meadow was concentrated around this shrub. Likewise, OVV activity at site 8 was high in Wood's rose and common reed (Phragmites australis). Runways typically extended short distances into surrounding grass and connected neighboring shrubs. In irrigated pasture (sites 9 and 10), OVV activity was conspicuous in patches of dense herbaceous vegetation and along fence lines. At site 9, livestock grazing had reduced most grasses to short stubble, and OVV activity was high only in 4 patches of ungrazed rushes. Patch diameter ranged from $4 \mathrm{~m}$ to $10 \mathrm{~m}$. One complex of runways and burrows was located entirely in stubble. Both woody vegetation growth and OVV activity were high along a fence with a parallel irrigation ditch.

Vole activity appeared to be concentrated near available waterways (e.g., natural stream courses, irrigation ditches, and former Owens River meanders). Whether OVV activity was actually higher near waterways and other site features could not be determined, as activity may simply be more conspicuous where dense grass is absent.

Average annual precipitation in Owens Valley has been below the long-term average since 1999, and, at the time of the study, populations of all small mammal species were likely depressed due to drought conditions. Beatley (1969) and Ernest et al. (2000) noted that drought resulted in depressed small mammal populations in arid regions. Drought may explain the presence of old OVV sign in currently unoccupied sites. In wet years with high plant production, these sites may be occupied by Owens Valley voles dispersing from adjacent areas.

As might be expected in an arid environment, irrigation is a primary factor in OVV distribution. Except in 1 case, all sites with captures of Owens Valley voles were irrigated. Site 8 (riparian scrub) was not artificially irrigated, but flooding from the creek provided some natural irrigation and allowed the persistence of dense herbaceous patches. Irrigation not only increases overall herbaceous vegetation density, but it also encourages the growth of beardless wildrye, which requires intermediate levels of moisture. Cockburn and Lidicker (1983) and Ostfeld et al. (1985) showed that California voles preferred patches of beardless wildrye to other microhabitats. In our study, sites with the highest sign indices also had dense beardless wildrye cover.

Use by Owens Valley voles of microhabitat islands such as shrubs, fence lines, and rush patches deserves consideration in the development of management plans. The importance of cover in microtine population dynamics is well documented (Birney et al. 1976, Getz 1985). It is likely that Owens Valley voles used 
patches of cover as refuge when macrohabitat quality was diminished through land uses such as mowing or grazing (Hovland et al. 1999) or through seasonal and interannual changes in herbaceous vegetation density.

Comparing relative OVV abundance between vegetative communities through livetrapping may be inefficient. The number of captures per 100 trap-nights was probably an unreliable index of population abundance due to differences in individual trap avoidance that could not be estimated or corrected. Lack of correlation between OVV activity and OVV captures could indicate that trap avoidance might be inversely related to food availability. Thus, capture numbers may be lower at sites with relatively high resource availability and OVV density, and higher at sites with low resources and low OVV density. Researchers studying the sagebrush vole (Lemmiscus curtatus), a species associated with Great Basin shrub-grassland plant communities, also have reported inconsistency in trapping success (Moore 1943, Allred 1973). In summary, based on our research it appears that the Owens Valley vole is uncommon but widespread, occurring across many plant communities in tall, dense patches of vegetation.

We thank the Los Angeles Department of Water (LADWP) for access to its property and Debbie House in particular for her indispensable help in arranging the study. We thank LADWP lessees, especially Walt Schober, for access to their leases; Mike and Tess Morgan for assisting with logistics; Janice Crenshaw for manuscript preparation; and 2 anonymous referees for review comments.

\section{Literature Cited}

AllRed, D.M. 1973. Small mammals of the National Reactor Testing Station, Idaho. Great Basin Naturalist 33:246-250.

BAILEY, V. 1898. Descriptions of eleven new species and subspecies of voles. Proceedings of the Biological Society of Washington 12:85-90.

. 1900. Revision of American voles of genus Microtus. North American Fauna 17:1-88.

1915. Revision of pocket gophers of the genus Thomomys. North American Fauna 39:1-136.

Beatley, J.C. 1969. Dependence of desert rodents on winter annuals and precipitation. Ecology 50:721-724.

Birney, E.C., W.E. Grant, and D.D. Baird. 1976. Importance of cover to cycles of Microtus populations. Ecology 57:1043-1051

Brown, J.H. 1973. Species diversity of seed-eating desert rodents in sand dune habitats. Ecology 54:775-787.
Brown, J.H., And G.A. Lieberman. 1973. Resource utilization of and coexistence of seed-eating desert rodents in sand dune habitats. Ecology 54:788-797.

[CDFG] California Department of Fish and Game. 2001. Special animals list, California Natural Diversity Database. Wildlife and Habitat Data Analysis Branch. Sacramento, CA.

Cockburn, A., And W.Z. Lidicker, Jr. 1983. Microhabitat heterogeneity and population ecology of an herbivorous rodent, Microtus californicus. Oecologia 59:167-177.

ElLiot, D.G. 1903. Descriptions of twenty-seven apparently new species and subspecies of mammals. Field Columbian Museum. Publication 87, Zoological Series 3:239-261

Ernest, S.K., J.H. Brown, and R.R. Parmenter. 2000. Rodents, plants, and precipitation: spatial and temporal dynamics of consumers and resources. Oikos 88:470-482.

Ford, R.G., AND F.A. Pitelka. 1984. Resource limitation in populations of the California vole. Ecology 65: 122-136.

GetZ, L.L. 1985. Habitats. Pages 286-309 in R.H. Tamarin, editor, Biology of New World Microtus. American Society of Mammalogists, Special Publication No. 8. $893 \mathrm{pp}$.

GrinnelL, J. 1922. Geographical study of the kangaroo rats of California. University of California Publications in Zoology 24:1-124.

HaLl, E.R. 1981. The mammals of North America. Volume 2. J. Wiley and Sons, New York.

HaLl, E.R., AND F.H. DaLe. 1939. Geographic races of the kangaroo rat, Dipodomys microps. Occasional Papers of the Museum of Zoology, Louisiana State University $4: 47-63$.

HolLand, R.F. 1986. Preliminary descriptions of the terrestrial natural communities of California. California Department of Fish and Game. Sacramento, CA.

Hollister, N. 1913. Three new subspecies of grasshopper mice. Proceedings of the Biological Society of Washington 26:215-216.

1914. A systematic account of the grasshopper mice. Proceedings of the United States National Museum 47:427-489.

Hovland, N., H.P. AndReassen, And R.A. Ims. 1999. Foraging behavior of the root vole Microtus oeconomus in fragmented habitats. Oecologia 121:236-244.

KeLlogG, R. 1918. A revision of the Microtus californicus group of meadow mice. University of California Publications in Zoology 21:21-24.

Kenagy, G.J. 1973a. Adaptations for leaf eating in the Great Basin kangaroo rat, Dipodomys microps. Oecologia 12:383-412.

1973b. Daily and seasonal patterns of activity and energetics in a heteromyid rodent community. Ecology 54:1201-1219.

Krebs, C.J. 1966. Demographic changes in fluctuating populations of Microtus californicus. Ecological Monographs 36:239-273.

LIDICKER, W.Z., JR. 1960. An analysis of intraspecific variation in the kangaroo rat Dipodomys merriami. University of California Publications in Zoology 67:125218.

1980. The social biology of the California vole. Biologist 62:46-55.

Moore, A.W. 1943. Notes on the sage mouse in eastern Oregon. Journal of Mammalogy 24:188-191. 
Matson, J.O. 1976. The distribution of rodents in Owens Lake region, Inyo County, California. Natural History Museum of Los Angeles County, Contributions in Science 276:1-27.

Nelson, F.C. 2004. Ecology of Owens Valley vole. Master's thesis, Department of Wildlife and Fisheries Sciences, Texas A\&M University, College Station.

OstFeld, R.S., W.Z. Lidicker, JR., AND E.J. Heske. 1985. The relationship between habitat heterogeneity, space use, and demography in a population of California voles. Oikos 45:433-442.
Tamarin, R.H. 1985. Biology of New World Microtus. American Society of Mammalogists, Special Publication No. 8. 893 pp.

Village, A., AND D. MYhill. 1990. Estimating small mammal abundance for predator studies: snap-trapping versus sign indexes. Journal of Zoology 222:681-689.

Received 9 June 2005 Accepted 22 March 2006 